Maurice A. Deane School of Law at Hofstra University Scholarly Commons at Hofstra Law

Hofstra Law Faculty Scholarship

2002

\title{
Law Schools and Family Court Reform
}

Andrew Schepard

Maurice A. Deane School of Law at Hofstra University

Follow this and additional works at: https://scholarlycommons.law.hofstra.edu/faculty_scholarship Part of the Family Law Commons

\section{Recommended Citation}

Andrew Schepard, Law Schools and Family Court Reform, 40 Fam. Ct. Rev. 460 (2002)

Available at: https://scholarlycommons.law.hofstra.edu/faculty_scholarship/529

This Article is brought to you for free and open access by Scholarly Commons at Hofstra Law. It has been accepted for inclusion in Hofstra Law Faculty Scholarship by an authorized administrator of Scholarly Commons at Hofstra Law. For more information, please contact lawcls@hofstra.edu. 


\title{
LAW SCHOOLS AND FAMILY COURT REFORM
}

\author{
Andrew Schepard
}

\begin{abstract}
Family courts are underfunded and overwhelmed, and the quality of representation provided by counsel in family court cases is problematic. This article discusses what role law schools can play in promoting family court reform. It argues that law school involvement in family court is consistent with the law school's core missions of education, research, and public service. The article illustrates how law schools can be involved in family court reform by discussing interdisciplinary projects of the Center for Children, Families and the Law of Hofstra University and North Shore-Long Island Jewish Health Systems. Finally, the article identifies some lessons to be learned if law schools want to be involved in family court reform.
\end{abstract}

\section{THE TROUBLED STATE OF FAMILY COURTS AND FAMILY LAWYERS}

Family-related disputes are the fastest growing category of all disputes brought to courts and constitute about $25 \%$ of all state court dockets.' As a chart of court filings from the state of Florida between 1986 and 1998 graphically illustrates (see Figure 1), family court filings have increased in recent years while the civil and criminal docket seems to be stable or actually has decreased.

For the sake of children and families, one hopes that the future growth of the Dow Jones Industrial Average will be as great as the recent increase in family disputes and that the growth of family disputes will, in turn, slip into recession. This is, however, a very unlikely future. There are no signs that the increase in family court filings will decrease.

Our family courts are not fully prepared to meet the challenges of an ever-expanding caseload created by more and more family disputes involving troubled parents and children. They are disorganized, overcrowded, underfunded, and overwhelmed. The average caseload of a New York Family Court judge is 2,500. ${ }^{2}$ In Brooklyn, New York, in 1997, family court cases "received slightly over four minutes before a judge on the first appearance and a little more than eleven minutes on subsequent appearances." Instead of being the highest priority of the judicial system, family courts seem to be their lowest rung, where judges are paid less, support facilities are nonexistent, and new judges are sent for a kind of mandatory service obligation before finding their way into presiding over more prestigious contract disputes or auto accident cases.

The problem is that our priorities really should be the opposite. The best judges and facilities should be available in the family court. Family court litigants have complex and interrelated legal, emotional, and social service problems that must be addressed in a coordinated manner to meet the needs of children and parents. They need highly skilled judges, lawyers, and mental health professionals to help devise and implement case management plans. Furthermore, the litigants are not happy with the family court. Parents in custody disputes arising from divorce and separation, for example, are very disaffected with the courts and the

Author's Note: This article is an expanded version of a presentation made at the Association of American Law Schools Section on Family and Juvenile Law Panel on Court Reform, Family Law and the Role of Teaching and Scholarship at the AALS 2002 annual meeting in New Orleans on January 4, 2002.

FAMILY COURT REVIEW, Vol. 40 No. 4, October $2002 \quad 460-472$

DOI: $10.1177 / 153124402237550$

C 2002 Association of Family and Conciliation Courts 


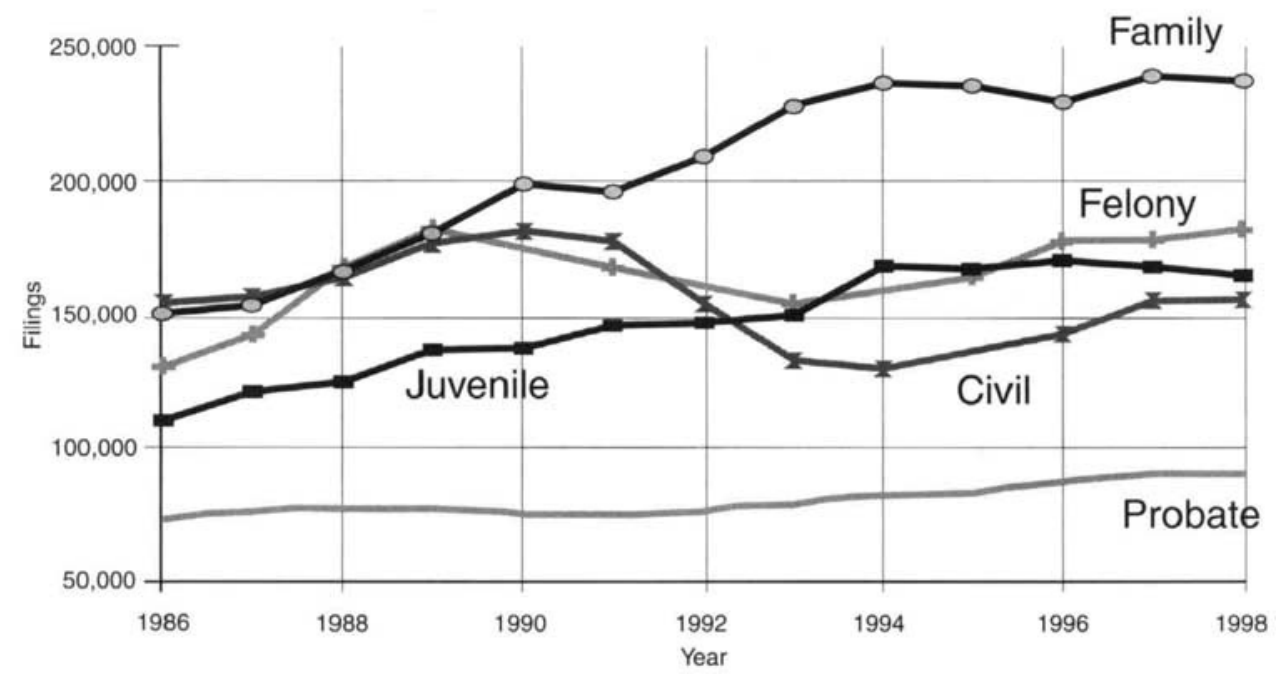

Figure 1. Circuit court filings by division (statewide, 1986-1998).

SOURCE: Summary Reporting System, Office of the State Courts Administrator, October 8, 1999.

lawyers who serve them. A national commission recently has reported survey results in which $50 \%$ to $70 \%$ of parents characterized the legal system to be "impersonal, intimidating and intrusive."4 The Oregon Task Force on Family Law, a legislatively authorized interdisciplinary reform group, has summed up public dissatisfaction after extensive public hearings on that state's divorce system: "The public is disgusted with the adversarial model of managing divorce." 5

Nor are litigants terribly happy with the quality of their lawyers' work. The United States experienced significant growth in the number of lawyers in the last half of the 20th century. "Sometime during the year 2000 the United States likely [has] met the magic benchmark of having one million lawyers. ... The nation [has] shifted from one lawyer for every 627 people in 1960 to one lawyer for every 260 as of the year $2000 .{ }^{\prime 6}$ Yet, the supply of lawyers for poor people in family courts seems to be dwindling. The New York Times recently reported, for example, that the New York City Family Court caseload has grown by one third in the past decade, but the number of private counsel available to represent the poor has shrunk by $15 \%$, creating a crisis in the processing of child protection cases. ${ }^{?}$

The growth in the number of pro se litigants in family court has been nothing short of phenomenal, as illustrated by the chart prepared by the Family Division of the Circuit Court for Baltimore City, Maryland (Figure 2).

Most family court litigants cannot pay for counsel and are forced to represent themselves if they are not assigned counsel through constitutional or statutory mandates. A small but increasing segment of the middle and upper classes that can afford lawyers, however, do not want them because of distrust of the profession. ${ }^{8}$ As the Oregon Task Force on Family Law also has told its governor and legislature, 


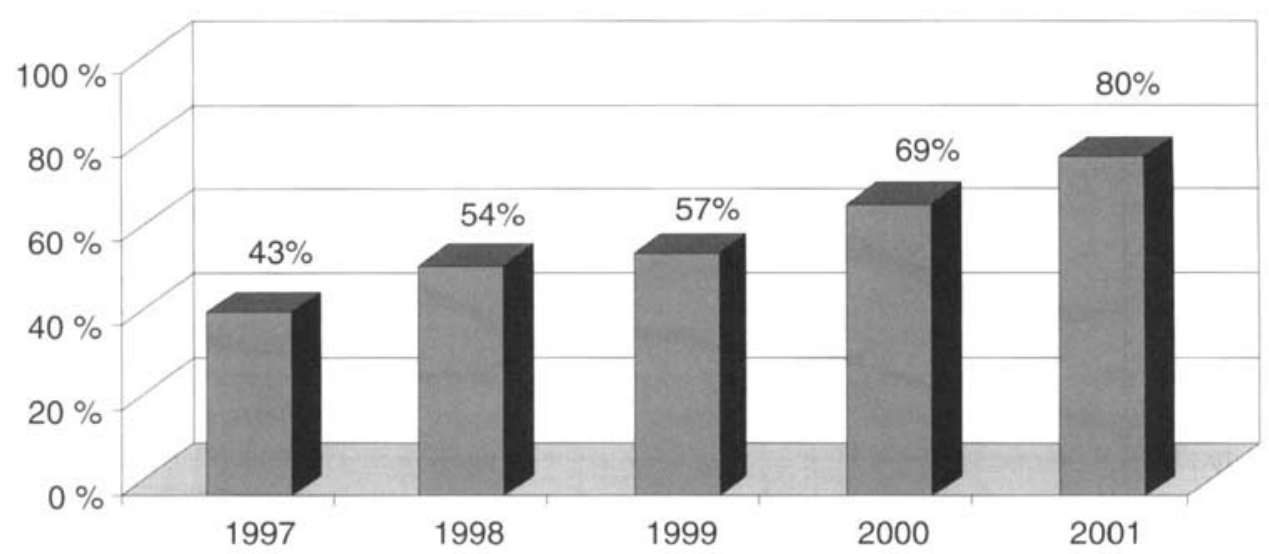

Figure 2. Growth of pro se litigants in family division.

SOURCE: Office of the Assuciate Administrator, Family, Circuit Court for Baltimore City.

The increasing trend of pro se filings is accelerating.... Many pro se litigants can afford lawyers. They do not seek the legal representation they need because they fear that to consult a lawyer would be to "shake hands with the tar baby." They fear getting sucked into a vortex of conflict."

In part, litigant distrust of counsel is magnified by the cynical message some divorce lawyers seem to convey to clients. Some research indicates that many divorce lawyers tell their clients that the court system does not reach rational results, that their clients are its victims, and that their only hope is that the lawyer can manipulate the system on the client's behalf through insider knowledge. ${ }^{10}$ This advice is a kind of family law version of the dark vision of the legal process in the Paul Newman movie, The Verdict, and certainly cannot be a confidence booster in the quality of the family court system for clients or the public.

A recent empirical study reported "an overall consensus that the attorney's roles and responsibilities in the divorce process are not translating into actual practice. The parents and children did not feel they had adequate representation through guidance, information, attention or quality of service." "Parents in the survey felt that the process was too long and never finalized, too costly, too inefficient, and was taking control of their lives. "Many of the parents did recognize that they were already feeling angry and hostile, but 71 percent of them maintained the legal process pushed those feelings to a further extreme."12

Malpractice claims against divorce lawyers seem to be higher than those against any other branch of the profession, ${ }^{13}$ in part because many clients are angry when they start and deeply emotionally disappointed by what transpires in adversarial process. Lawyers who take a highly adversarial approach to family court disputes often do their clients a disservice. Their clients generally benefit from participating in an alternative dispute resolution processes. Continuing bonds between family members after they leave the courtroom often make adversary procedure counterproductive and collaborative problem solving through ADR particularly appropriate.

In custody disputes, for example, children are put at risk from continuous parental conflict and generally need a civilized relationship with both parents after divorce. Researchers have found that 
as the parental alliance weakens, the behavior standards for the children decline. If parents quarrel openly in front of the children, and show contempt for each other, the atmosphere of mutual respect that underlies their joint authority and effective co-parenting is seriously weakened. ${ }^{14}$

Mediation and parent education offer parents the opportunity to devise their own parenting plans rather than have a court impose one on them. Parents are much more satisfied with the results when compared to litigated cases, and the settlements are generally of better quality. ${ }^{15}$

The same need for collaboration and planning for the child's future welfare also applies in child protection matters. Research on mediation programs in California and Florida child dependency cases report high settlement rates (75\% in California and $86 \%$ in Florida). The research suggests that as compared to nonmediated cases, agreements in dependency mediations tend to be more detailed, are more likely to include provisions for services to children and family members, and are more likely to make use of relative foster care. Furthermore, the study has found that both parents and the professional participants (after initial suspicions were overcome) prefer mediation to court hearings, feeling that mediation gives them more opportunity to voice their points of view and personal respect. Parental compliance also seems better for mediated agreements, at least in the short run. ${ }^{16}$

\section{THE ROLE OF THE LAW SCHOOL IN FAMILY COURT REFORM}

The family court and the lawyers who represent clients in it thus face enormous challenges to help children and parents resolve disputes. My topic is, however, different than that of the other contributors to this special issue. It is not the state of the family court and what can be done to reform it, but whether law schools should play a role in that process. Based on some experience, my answer is a qualified "yes." As I discuss, I believe that law schools can make a valuable contribution to family court reform through education, research, and public service.

The qualification of my "yes" answer is that the law school's involvement in family court must be consistent with academic values. It also must be based on realistic expectations about how long and how hard it is to change the family court, and the reform effort must be allocated necessary resources and prestige. Under these conditions, law school involvement in family court reform also has great benefits for faculty, students, and the institution.

Law schools and professors can, of course, simply ignore the troubled state of family courts and family lawyers in planning their family law curricula and scholarship. Instead, we can concentrate on legal doctrine and the social policies that underlie them. Some law school faculty already think of family law as being of lower status than other fields of scholarship and teaching in part because of the low esteem in which family courts and lawyers are held. This perception in academia mirrors the perception of hopelessness for improvement of family courts in some segments of the courts and the bar. Certainly, the current status of overburdened family courts and underprepared, overadversarial, and unappreciated lawyers gives little ground for optimism that change will come rapidly or that law schools can (or should) do anything to initiate it.

It is, however, possible to imagine an alternate vision of the law school's role in family court reform- - as a positive agent for change over the long term. Law schools can create a platform for family court reform in their communities by 
- creating an awareness of the problems of the family court and an interest in its reform among all students;

- educating those law students who want specialized training to represent clients in family court effectively, by emphasizing interdisciplinary understanding, client representation skills, problemsolving values, and alternatives to litigation;

- developing research agendas and model programs that address the problems of the family court; and

- serving as honest brokers to bring family court stakeholders together to talk about their hopes and problems and to find common ground for positive change.

I hope to illustrate how law schools can productively participate in family court reform by describing the education, research, and public service projects that developed at Hofstra Law School and to highlight what law students do in each. After I describe Hofstra's family court reform-related activities, I offer some reflections on the benefits and problems of law school involvement in family court reform that are the product of my experience in helping to create and shape it. ${ }^{17}$

The unifying theme of Hofstra Law School's projects is that they are interdisciplinary and result from a formal alliance between the law school and a major provider of mental health services for families and children in our area. The projects include simulation-based interdisciplinary courses, a child advocacy clinic, a law-review-type journal, a court-affiliated education program for divorcing and separating parents and children, and other court improvement projects.

\section{THE CENTER FOR CHILDREN, FAMILIES AND THE LAW OF HOFSTRA UNIVERSITY AND LONG ISLAND JEWISH HEALTH SYSTEM}

The Center for Children, Families and the Law of Hofstra University and the North Shore-Long Island Jewish (LIJ) Health System is a joint venture with North Shore-Long Island Jewish Health Systems, a major health care provider in the New York City area. Its aim is to organize interdisciplinary education, research, and public service programs for the benefit of children and families in court. Hofstra Law School is the organizing force of the center on the Hofstra campus, and the Department of Child and Adolescent Psychiatry of North Shore-LIJ, a research and training center for child psychiatry fellows and child psychology trainees, is the main participant in the Center's activities at North Shore-LIJ.

\section{A. EDUCATION}

The fundamental educational effort of the Center is to educate a small number of future lawyers and mental health professionals to become familiar with each other's professions, language, and values and to make a career commitment to work in the family court. To accomplish that goal, we use traditional classroom instruction, simulations and a live client clinic, and a research seminar.

\section{Simulation-Based Interdisciplinary Courses}

The center offers two courses in which law students are educated jointly with North Shore-LIJ's child psychiatry fellows and child psychology trainees. The first course focuses 
on negotiation and mediation, while the other focuses on the role of lawyers and mental health experts in child custody disputes. Each class meeting combines education in law, child and family development, and professional skills, such as interviewing, counseling, negotiation, or preparation for the direct and cross examination of a mental health expert. The focus is on how lawyers and mental health professionals can work together and problem solve for families and children. The law and mental health students, for example, read the same books on problem-solving behavior and discuss how the concepts can be implemented in particular cases. ${ }^{18}$ The courses end in simulated mediation sessions conducted by mediators or in child custody trials presided over by judges based on complex simulated case files created by law and mental health faculty. Law and mental health students work together under faculty supervision as teams to prepare for these events.

\section{The Child Advocacy Clinic}

The core for interdisciplinary education of future child advocates is the Center's Child Advocacy Clinic. Law faculty and students work with North Shore-LIJ faculty and mental health trainees to assist some of the most troubled children in American society by serving as law guardians in child protection cases. Faculty and students participate in a joint weekly seminar and weekly case review conferences. Mental health trainees serve as consultants to the law students in developing techniques for client interviews, reading case files and child and family case histories, preparing children to testify, developing service plans, and so forth. Senior staff members from both institutions carefully supervise all work by law students and mental health trainees on these cases.

\section{The Family Court Review (FCR)}

On the student research and writing front, $F C R$ is published by Hofstra law students with consulting help from North Shore-LIJ mental health students and staff, much in the manner of a traditional law review. $F C R$ is an interdisciplinary quarterly research journal sponsored by the Association of Family and Conciliation Courts (AFCC). The main difference between $F C R$ and the traditional law review is that $F C R$ is interdisciplinary, publishing articles from lawyers, judges, mental health professionals, court administrators, mediators, scholars, researchers, and practitioners alike. An interdisciplinary editorial board that reviews submissions also heavily influences $F C R$ 's article selection process.

The law student staff members are chosen through a competitive application process and receive academic credit for their work. They both write a research paper that can result in a publishable note and perform editorial functions. Through work on $F C R$, law students make a long-term contribution to improving family court, as well as to refining their research and writing skills. $F C R$, for example, recently published a special issue on pro se litigants in family court and unbundled legal services. ${ }^{19}$ That issue includes a student survey of the strengths and weaknesses of every Web site operated by court systems to help pro se divorce litigants and recommendations for reform based on best practices. ${ }^{20}$

\section{The Child and Family Advocacy Fellowship Program}

Family law practice in a child advocacy center, a legal aid society, or a child protection bureau is not as lucrative as commercial practice, and few students enter it. They are especially discouraged from pursuing such careers by a daunting debt burden created by legal 
education. Hofstra has created a competitive fellowship program to encourage law students who are interested in a child and family advocacy career. After graduation, fellows are expected to use their specialized training to represent the legal interests of children and families. We define the acceptable jobs broadly to include representation of clients, legislative and administrative advocacy, work at a foundation helping children, or almost any job that is an attempt to improve the lives of children and families. If a graduate is unwilling or unable to meet this expectation, he or she has an obligation to reimburse the law school for fellowship support so that these monies can be reinvested in future fellows.

\section{B. RESEARCH AND PUBLIC SERVICE}

The Center also is engaged in a number of family court reform-related activities that require outside funding and involve students and faculty with family court stakeholders.

\section{P.E.A.C.E. (Parent Education and Custody Effectiveness)}

The center's family court reform efforts began with the development of P.E.A.C.E., a court-affiliated, interdisciplinary education program for divorcing and separating parents and children designed to promote their responsible management of family conflict. We received a grant from the State Justice Institute to develop a model curriculum and to create and evaluate pilot programs. The result was a video and curriculum manual, several pilot programs in New York State courts, positive evaluations, several conferences, and law review articles. $^{21}$

I believe that P.E.A.C.E. made a contribution to the widespread implementation of courtaffiliated parent education programs around the United States and abroad to the point where they are an integral part of the divorce and separation process in many states. ${ }^{22}$ We are currently working on developing educational programs for repetitive litigants and for children of divorce and separation.

Law students, working with mental health graduate students, made enormous contributions to P.E.A.C.E., which became the equivalent of a clinical program's law reform effort. Students researched the legal authorization for parent education programs and drafted model statutes and regulations. They helped write and document the curriculum manual, handbooks for parents and children, and research protocols to test how the programs were being received. They provided research help on grant requests. Students made presentations about P.E.A.C.E. to bar groups and other interested constituencies. They organized training programs for presenters, registered program participants, and ensured that programs went smoothly. In short, whatever success P.E.A.C.E. had is largely attributable to the efforts of the students who helped develop it.

\section{Model Standards of Practice for Family and Divorce Mediation}

Center faculty and students also worked with family law and family mediation groups and with family violence experts in a multiyear project to develop Standards of Practice for Family and Divorce Mediation. The motivation for the project was, in effect, to create a consensus description for the role of the family mediator so that lawyers, judges, mental health professionals, and the public would know what to expect from the profession. Students performed various research tasks relating to the standards, including a national survey of 
family and divorce mediation statutes published by $F C R .^{23}$ The result was standards that received the support of the American Bar Association's Coalition on Domestic Violence were approved by the American Bar Association's House of Delegates and a number of family mediation groups, and were the subject matter of a law review article. ${ }^{24}$

\section{Model Family Court Projects}

The Center also works with court systems in several states to develop programs to improve the quality of the experience for children and parents in court. We are currently working on a plan to develop a screening protocol for high-conflict custody litigants so that these families are identified early on in the life of their potentially endless litigation and appropriate mental health and dispute resolution services are provided. Students are heavily involved in the planning and research effort, which is still in relatively rudimentary stages.

\section{BENEFITS AND BURDENS OF LAW SCHOOL INVOLVEMENT IN FAMILY COURT REFORM}

The Center for Children, Families and the Law did not begin with a conscious developmental plan. To paraphrase another New Yorker (and well-known child custody litigant), Woody Allen, "eighty percent of the Center's success is showing up." ${ }^{25}$ The Center's courses and projects began with a desire to change the emotional climate for children caught in the middle of their parents' divorce and separation conflict. The P.E.A.C.E. Program was born. We looked around for support for this fledgling idea from any place we could find it. From that beginning, the Center grew with some luck, persistence, increased faculty interest, administrative support, and available funding, all of which took time, persuasion, and successful experience to build.

We have learned something about the burdens and benefits of intensive law school involvement in family court reform from the center's development. I offer these reflections in the hope that those of you who are interested in promoting family court reform will avoid, in the words of yet another New Yorker, Yogi Berra, "déjà vu all over again."26

\section{Involvement in Family Court Reform Fits the Law School's Mission}

The most important lesson is a positive one- the law school benefits from involvement in family court reform because that involvement well serves the law school's mission of teaching, scholarship, and public service. Faculty and students involved in reform efforts are motivated to study and probe because they feel they can make a difference. They are exposed to different disciplines, different value systems that challenge their reliance on adversary procedure, and individual rights. A wonderful example is the fascinating class we have in our interdisciplinary simulation courses in which the law students try to explain to the mental health students why mental health professionals are mandated child abuse reporters but lawyers are not (at least in New York). ${ }^{27}$ Mental health professionals tend to be shocked by this. The law students are forced to explain and defend the values of the adversary system and client confidentiality to others who value patient confidentiality but start from different premises about their obligations to children. Class discussions and research and writing tend to be more interesting and dynamic when they involve people with very different perspectives than one's own. 
Law students also learn critical practice skills and values when exposed to family court cases either in simulation or live client clinic. They learn the importance of interviewing, counseling, and negotiation. They learn the delicacy of involving themselves in trying to resolve ongoing family problems and the difference between problem solving and adversarial behavior.

Law students involved in family court work also learn that they need to collaborate with and learn from others. Lawyers who represent parents and children in family court need mental health expertise that is simply not available in traditional legal education. Law students do not have to become psychologists or social workers to represent family court clients effectively. They do, however, have to be able to converse intelligently with those professionals and know where to get help from mental health experts when they need it.

The lawyer for a child, for example, must understand what his or her client can comprehend about the legal process to determine what role the child can play in directing the lawyer's representation. The lawyer, thus, must understand mental health principles of child development. Two of our students recently published a case study in which they analyzed these problems in the context of an actual clinic case. They applied the varying standards of practice for lawyers who represent children to it, ${ }^{28}$ a learning experience that integrates actual practice with reflective research and writing. The trial of a case where a child testifies requires the lawyers for parents and children to have special training in mental health about the reliability of children's testimony, how to shield children from emotional damage that may result from courtroom confrontations, and how to conduct direct and cross examination of mental health experts. Mediation of family disputes requires lawyers for parents and children to help shape a parenting plan that is consistent with a child's development stage and that protects the child from harm caused by abusive or neglectful parents. It is difficult for a lawyer for a child to determine what kind of foster care or juvenile placement is suitable for a child without understanding something of social work principles concerning family reunification. This is all information one cannot learn from a family law casebook in a conventional basic family law course.

A final benefit of the law school's involvement in family court reform is its contribution to the community and the concrete benefits to the law school that result. The family court needs help. In addition, reform efforts directed at important social problems give deans, conference organizers, and fund-raisers evidence of the law school's good citizenship to discuss with potential donors and state legislators. Grants can be written, money can be raised, and positive press clippings can be generated. Administrators like that.

\section{Law School Involvement in Family Court Reform Must be Consistent With Academic Values}

The major concern I have about law school involvement in family court reform is that it must be consistent with the role and values of an academic institution. Fairness to opposing views and skepticism about proposed change are key components of academic dialogue. Faculty who play the role of reformer must develop a vision for change with which others may not agree. For example, mediation of many types of family disputes, a key component of some proposals for reform in family court procedures (including my own), remains controversial, despite generally positive public reaction and research findings. ${ }^{29} \mathrm{~A}$ law school that develops a reform orientation has an obligation to expose its students and faculty not only to 
those who favor change but also to those who question it. Even in promoting change, we must remain academics as well as advocates.

Law school projects also must have academic content and must link to our core mission of education, research, and public service. Law schools cannot provide long-term funding for resource-starved family court support services or serve as legal aid societies for pro se litigants. Satisfying unmet service needs with student labor should not be a goal of our involvement in family court reform - their education is our highest priority. Funding for courts, court services, and lawyers for the poor is ultimately the responsibility of the state legislative process. We can try to influence the legislative process, but we do not have the responsibility to replace it. Grants and donations, however, are available for model service projects with a law school base. Such funding tends to disappear over time, and the services supported by it must be absorbed in permanent funding elsewhere. Law professors who engage in family court reform projects need to think about how they will continue the effort when the grant funds run out.

\section{Creating a Climate for Reform in the Family Court Bureaucracy Requires Persistence and Political Skills}

Law professors who undertake family court reform also must have realistic expectations about the pace of change and must prepare for frustration and disappointment. They must ask themselves how they can influence the bureaucracy and culture of family court. Change in family court is incremental. Family court stakeholders (judges, lawyers, court personnel, social service agencies) are often quite comfortable with current practices and resist change promoted by reformers whom they see as theoretical idealists or uninformed critics. Opposition to change can come from unexpected quarters, as I learned when some judges opposed implementation of P.E.A.C.E. as an interference with their relationship with the litigants.

Those of us who work on family court reform must constantly keep in mind Chief Justice Arthur Vanderbilt's admonition, "Judicial reform is no sport for the short-winded or for lawyers who are afraid of temporary defeat." ${ }^{30}$ Or, as Yogi more colloquially said, "It ain't over 'til it's over." ${ }^{31}$ Law professors who want to bring about change in the family court must find allies within the bureaucracy (strong judicial leadership is essential), establish that their proposals are feasible in the real world, and try to anticipate how dissenters in the system who can sabotage reform efforts can be influenced. There are allies out there for the reform effort. We need to find and nurture them.

\section{Time, Money, and Rewards are Essential if the Law School Is to Effectively Promote Family Court Reform}

Law school involvement in family court reform is not without costs or risks. Writing grant proposals, working with experts from other disciplines, organizing conferences of stakeholders, creating innovative educational offerings, and serving on law reform commissions take time and effort, often without a direct link to footnotes, tenure, and academic prestige. If we are serious about law schools participating in the family court reform effort, we need to find rewards for the activities that promote it. Good community and law school citizenship developing by promoting family court awareness and reform should be an important value in hiring and promoting law faculty. 


\section{THE FUTURE CHALLENGE OF REACHING THE GREAT MAJORITY OF LAW STUDENTS}

Most of the efforts of the center have been devoted to educating a small number of law students in an interdisciplinary environment. We hope these students will make family law practice a career commitment. We certainly need to devote effort to at least making the rest of the student body aware of the problems of the family court. They, their family members, colleagues, and friends are directly affected by the current system as consumers of that system. As citizens and professionals, law students are future bar association leaders, judges, state legislators, and community leaders with power to promote change.

The best place to educate most law students about the problems of the family court and its potential for reform is in the basic family law course. Most (not all) law students seem to take it. An informal e-mail survey of AALS Family Law Section members did not reveal any school where family law is a required course. Most (not all) survey respondents, however, indicated that most of their students take the course because it is on the bar examination. Enrollments in the basic family law course seem to be substantial where it is required on the bar, and they decline when it is not.

Whether family law should be a required course in law school is a subject for another day and another panel. It is, however, hard to understand why law students graduate without exposure to how the fundamental social institution of the family is treated by the legal system. My current focus is more modest-if we are serious about law schools promoting family court reform, we should include a unit describing the workings, problems, and proposals for reform of the court in the basic course. Because of the dramatic changes in family structure and family law doctrine in recent years, there are enormous pressures on the scope of the basic course. Our books and content have expanded enormously. Yet, including a unit within the basic course on the organization and structure of the family court and the challenges it faces is the only way that most law students can become familiar with that court's unique status and nature. We need to develop effective teaching materials to reach the great majority of students in a large-class format to achieve this goal.

\section{CONCLUSION}

Law school involvement in family court reform is not a magic bullet to improve the chronic problems of that troubled but essential institution. I am optimistic enough to believe that over time, law schools can make a positive difference in the treatment that children and families receive from the legal system through education, research, and public service. I also believe that it is in the law school's best interests to do so. We can do good and do well at the same time.

\section{NOTES}

1. Brian J. Ostrom \& Nell, B. Kauder, Examining the Work of State Courts, 1995: A Nationat. Perspective from the Court Statistics Project 39 (1996).

2. John Sullivan, Chief.Iudge Announces Plan to Streamline Family Court, N.Y. Times, Feb. 25, 1998, $\$$ B at 7 , col. 3 (reporting results from a September 1997 study by the Fund for Modern Courts). 
3. Id.

4. See United States Commission on Child and Family Welfare, Parenting Our Children: In the Best Interests of the Nation. A Report to the President and Congress 38 -39 (1996).

5. Oregon Task Force on Family Law, Final Report to Governor John A. Kitzhaber and the Oregon LEGISLATIVE ASSEMBLy 2 (1997). The Oregon Legislature established the bipartisan interdisciplinary Task Force on Family Law to review the state's divorce system. See William Howe III \& Maureen McNight, Oregon Task Force on Family Law: A New System to Resolve Family Law Conflicts, 33 FAM. \& ConCILIATION CTs. REv. 173 (1995).

6. Kathleen M. Sullivan, Access to Justice: The Social Responsibility of Lawyers: The Good that Lawyers Do, 4 WAsh. U. J. L \& POL'Y 7 (2000).

7. Somini Sengupta, Lack of Lawyers Crippling Family Court, Report Says, N.Y. Times, May 14, 2000, 1 at 35, col. 5 (describing report of New York City's Public Advocate).

8. Robert B. Yegge, Divorce Litigation Without Lawyers, 28 FAM. L. Q. 407 (1994).

9. Oregon TASk Force on Family LaW, Final Report, supra note 5, at 2.

10. Austin Sarat \& William L.F. Felstinger, Lawyers and Legal Consciousness: Law Talk in the Divorce Lawyer's Office, 98 Y ALE L.J. 1663, 1682-88 (1989) (summarizing results of their observations of interviews between divorce lawyers and their clients and arguing these conversations might contribute to the increasing view of the public that the legal process is "cynical instrumentalism").

11. Marsha Klein Pruett \& Tamara D. Jackson, The Lawyer's Role during the Divorce Process; Perceptions of Parents, Their Young Children and Their Attorneys, 33 FAM. L. Q. 283, 306 (1999).

12. Id. at 298.

13. See Ronald E. Mallen \& Jeffrey M. Smith, Legal. Malpractice $\$ 22.2$ at 330-333 (3d ed. 1989) (citing statistics collected by ABA's National Legal Malpractice Data Center indicating that "family law practitioners account for a significant percentage of all claims. Client relationship errors are much greater than average, the highest in all areas of law"): Stephen Labaton, Are Divorce Lawyers Really the Sleaziest? N.Y. Times, Sept. 5, 1993, \$ 4 (Week in Review) at 5 , col. 4

14. Eleanor E. Maccoby \& Robert H. Mnookin, Dividing the Child: Social and Legal Dilemmas of Custody 31 (1992).

15. Some of the supporting data are summarized in Andrew Schepard, The Evolving Judicial Role in Child Custody Disputes: From Fault Finder to Conflict Manager to Differential Case Management, 22 U. ARK. LITTLE ROCK L. REV. 395, 408-09 (2000).

16. Nancy Thoennes, An Evaluation of Child Protection Mediation in Five California Courts, 35 FAM. \& Concillation CTS. Rev. 184, 195 (Apr. 1997).

17. Hofstra, of course, does not have a monopoly on interdisciplinary programs to help improve the quality of representation of children and parents in the family court. Many other law schools have already involved themselves in family court reform. Barbara Babb, Jane Murphy, Michael Millemann, and Jana Singer have, for example, established wonderful collaborative projects with the Family Division of the Circuit Court for Baltimore City and the law schools of the University of Baltimore and the University of Maryland. I did not attempt any type of a comprehensive survey of law school activities for this article. I described a few programs at other schools in Andrew Schepard, Law and Children: Law School Programs Set to Improve Representation of Children, N. Y.L.J. Nov. 1, 2001 at 3, col. 1. See also Melissa Breger et al., Building Pediatric Law Careers: The University of Michigan Law School Experience, 34 FAM. L. Q. 531 (2000) (describing the University of Michigan's program).

18. They read, for example, Robert H. Mnookin, Scott R. Peppet, \& Andrew S. Tulumello, Beyond Winning: Negotiating to Create Value in Deals and Disputes (2001) and discuss the divorce case study that is contained in the last third of the book.

19. Special Issue: Unbundled Legal Services and Unrepresented Family Court Litigants, 40 FAM. CT. REv. 10 (2002).

20. Margaret B. Flaherty, How Courts Help You Help Yourself: The Internet and the Pro Se Litigant, 40 FAM. CT. REV. 93 (2002).

21. See Andrew Schepard, War and P.E.A.C.E.: A Preliminary Report and a Modei Statute on an Interdisciplinary Educational Program for Divorcing and Separating Parents, 27 U. Mich. J. L. REF. 155 (1993); Andrew Schepard, Parental Conflict Prevention Programs and the Unified Family Court, 32 FAM. L. Q. 95, 98-100 (1998).

22. At last count, 44 states had court rules or legislation allowing judges to mandate divorcing and separating parents court-affiliated educational programs. See Debra A. Clement, 1998 Nationwide Survey of the Legal Status of Parent Education, 37 FAM. \& ConClLIATION CTS. Rev. 219, 221 (1998) for a state-by-state listing.

23. Carrie-Anne Tondo, Rinarisa Coronel, \& Bethany Drucker, Mediation Trends: A Survey of the States, 39 FAM. CT. REv. 431 (2001) (state-by-state survey of mediation statutes and regulations). 
24. Andrew Schepard, An Introduction to the Model Standards of Practice for Family and Divorce Mediation, 35 Fam. L. Q. 1 (2001). See Model Standards of Practice for Family and Divorce Mediation, 39 Family CT. REv. 121 (2001) and 39 FAM. L. Q. 27 (2001).

25. BARTLETT's FAMiliar QuOTATIONS 767 (16th ed. 1992).

26. YOGI BERRA, THE YOGI BOOK 30 (1998).

27. See Andrew Schepard, Law and Children: A Lawyer's Obligation to Report Child Abuse, NEW YoRK LAW JOURNAL, May 13, 1999 at 3 for a short discussion of the issues involved, with citations to more extensive works.

28. Michael D. Drews \& Pamela Halprin, Determining the Effective Representation of a Child in Our Legal System: Do Current Standards Accomplish the Goal? 40 FAM. CT. REV. 381 (2002).

29. See Connie J.A. Beck \& Bruce D. Sales, Family Mediation: Facts, Myths, and Future Prospects (2001) for a recent review of the research.

30. Arthur T. Vanderbilt, Introduction to Minimum Standards of Judicial Administration xix (Arthur T. Vanderbilt ed. 1949).

31. BERRA, supra note 19, at 121.

Andrew Schepard is a professor of law at Hofstra University School of Law, the editor of the Family Court Review, and the codirector of the Center for Children, Families and the Law of Hofstra University and Long Island Jewish Health Systems. He can be reached via e-mail at lawazs@hofstra.edu. 